\title{
Effect of some Plant Leaves Extracts on Weight, Neutrophil and Lymphocyte Constituents of Cyclophosphamide-Induced Anaemia in Adult Male Albino Rats
}

\author{
*Dele-Olawumi Bukola, **Olanrewaju, O.I, ***Ayodeji, P.A, **Adedayo, E.O \\ *Nutrition and Dietetics Department, College of Health Sciences and Technology, Ijero-Ekiti, Nigeria \\ ** Nutrition and Dietetics Department, Rufus Giwa Polytechnic, Owo Ondo State, Nigeria \\ ***Nutrition and Dietetics, Department Ekiti state University teaching hospital, Ado Ekiti, Nigeria
}

Abstract

\section{Introduction}

Anaemia is a global public health problem, it is the most common disorder of the blood, affecting about a quarter of the people globally.

\section{$>$ Objective}

The effect of Sorghum bicolor, Carica papaya and Hibiscus sabdariffa leaves extracts on weight, Neutrophil and Lymphocyte Constituents of Cyclophosphamide-induced Anaemia in adult male albino rats was investigated.

\section{Materials and Method}

Aqueous extracts of Five hundred grams $(500 \mathrm{~g})$ of each of the pulverized leaves was obtained in each case. Forty non-drug treatment (40) adult male albino rats were randomly allotted to eight (8) groups of five rats each on the basis of body weight and their differences in weights did not exceed 5g. Anaemia was induced in the rats using Cyclophosphamide. Blood samples were collected from the rats for biochemical analysis. Hematological indices were determined using standard procedure. One-way analysis of variance (ANOVA) and Duncan Studentised New Multiple Range Test were used to separate and compare means. The differences in means were considered significant at $5 \%$ probability.

\section{$>$ Result}

The group treated with $400 \mathrm{mg} / \mathrm{kgbw}$ Sorghum bicolor showed highest decrease $(28.23 \%)$ in neutrophils. Similarly, the group treated with $400 \mathrm{mg} / \mathrm{kgbw}$ Sorghum bicolor had the highest increase in lymphocytes $(\mathbf{1 0 5 . 4 1 \%})$ compared to others. Sorghum bicolor was significantly $(\mathrm{P}<0.05)$ higher in of zinc, magnesium, manganese and phosphorus while Hibiscus sabdariffa has the highest content of iron

\section{Conclusion}

This study demonstrated that Sorghum bicolor, Carica papaya and Hibiscus sabdariffa leaf extracts would be beneficial in boosting blood volume and presents alternative to low cost management of nutritional Anaemia.
Keywords:- Plant Leaves, Neutrophil, Lymphocyte, Anaemia, Albino Rats, Cyclophosphamide.

\section{INTRODUCTION}

Anaemia is the reduction in the haemoglobin concentration of the peripheral blood below the normal range expected for age and sex of an individual (1). The World Health Organization (WHO) defines anaemia as a hemoglobin value below $13 \mathrm{~g} / \mathrm{dl}$ in men over 15 years of age, below $12 \mathrm{~g} / \mathrm{dl}$ in non-pregnant women over 15 years, and below $11 \mathrm{~g} / \mathrm{dl}$ in pregnant women (2). It is a condition in which the number of red blood cells or their oxygen carrying capacity is insufficient to meet physiologic needs. This varies for age, sex, and pregnancy status (1). However, the determination of hemoglobin concentration should always take the state of hydration and altitude of residence of an individual into consideration (1).

Anaemia is a global public health problem, it is the most common disorder of the blood, affecting about a quarter of the people globally (3). Iron-deficiency anemia affects nearly 1 billion of people (4). In 2013, anaemia due to iron deficiency resulted in about 183,000 deaths - down from 213,000 deaths in 1990 (5). It is more common in females than males (4) among children, during pregnancy, and in the elderly. Anaemia increases costs of medical care and lowers a person's productivity through a decreased ability to work (4). According to a review of nationally representative survey data from 1993-2005, the WHO estimates that more than 1.62 billion people are affected by anaemia (6). And one in four people is affected by anaemia worldwide $(22 ; 6)$. Severe anaemia is an important cause of morbidity and mortality in many parts of the world. The burden is higher in sub-Saharan Africa where it was associated with an increased risk of morbidity and mortality (7). Iron-deficiency anaemia is the final stage of irondeficiency that, if occurring during the critical period (aged $<2$ years) without early intervention, cause irreversible damage, preventing the child from reaching Neurodevelopmental milestones (8; 9). Iron deficiency anaemia (IDA) is an underlying risk factor for morbidity and mortality, it is estimated to be associated with 115,000 of the 510,000 maternal deaths (i.e. 22\%) and 591,000 of the $2,464,000$ prenatal deaths (i.e. $24 \%$ ) occurring annually 
around the world (10). Anaemia impairs cognitive development, reduced physical work capacity and in severe cases, increased the risk of mortality. Non-nutritional causes of Anaemia are numerous and diverse. In the developing world, common infections which may be both chronic and recurrent are associated with blood loss that can result in ultimately anaemia. In addition, inherited abnormal hemoglobin traits, acute hemorrhage and various chronic diseases are also contributing factors (6).

The use of plants for remedies has long been in existence and is among the most attractive sources for developing drugs (11). These ancient indigenous practices were discovered by series of 'trial and error' which then could not be substantiated by proven scientific theories (11). Medicinal plants and herbs are one of the crucial components as far as the contribution of biodiversity to society is concerned. Medicinal plants provide meaningful inputs for drugs $(12 ; 13)$. The World Health Organization estimated that $80 \%$ of the populations of developing countries rely on traditional medicines, mostly plant drugs, for their primary health care needs $(14 ; 15)$. In Africa and in most of the developing countries, plants or herbs has been in use to treat different ailment like diabetes, hypertension, diarrhea and anaemia but not much work has been done using Sorghum bicolor leaves, Carica papaya leaves and Hibiscus sabdariffa leaves to treat anaemia. Despite these traditional health care methods, African medicine is used by $80 \%$ of the rural populations and appears sure means of eradication of diseases. In the search of fighting against anaemia disorder, effect of Sorghum bicolor leaves, Carica papaya leaves and Hibiscus sabdariffa leaves extracts on hematological constituents in anaemia induced rats were investigated.

\section{MATERIALS AND METHODS}

\section{$>$ Materials}

The vegetables that were used for this study were the fresh leaves of Sorghum bicolor, Carica papaya and Hibiscus sabdariffa. The leaves were collected in the zoological garden of University of Nigeria, Nsukka and identified at the Herbarium unit of the Department of Plant Science and Biotechnology, University of Nigeria, Nsukka, Enugu state.

\section{> Preparation of samples for haematological analysis}

Five kilograms $(5 \mathrm{~kg})$ of each of the fresh leaves of Sorghum bicolor, Carica papaya and Hibiscus sabdariffa were weighed out using a digital balance scale. The leaves were sorted by removing extraneous materials, washed with tap water for five minutes and drained with the use of plastic sieve then spread evenly on trays and place in an open space under the shade which allowed for cross ventilation for seven days at room temperature. Then the dried leaves were pulverized to a fine powder, separately using Warburg laboratory blender. It was packaged in labeled polyethylene bags and stored in desiccators.

\section{$>$ Preparation of leaf extracts for rat studies}

Five hundred grams $(500 \mathrm{~g})$ of each of the pulverized leaves were soaked separately in $1500 \mathrm{ml}$ boiled and cooled distilled water and agitated intermittently for 12 hours. They were filtered using fine sieve of $4.75 \mathrm{~mm}$ mesh size (N0.4) to obtain the aqueous extracts in each case. The extracts were stored in an air tight Pyrex glass container in refrigerator. The required base dose was administered during the study using the formula

\section{Weight of rat $\times$ Dosage/ Concentration of extract 1000}

\section{$>$ Determination of the concentrate}

The concentration of the filtrate was determined by collection of $2 \mathrm{ml}$ of the aqueous sample into a container of a known weight. The samples in the container was allowed to dry in an oven dryer at $50^{\circ} \mathrm{C}$ for 12 hours to obtain crude extracts, heated to dryness and the weight taken and subtracted from the container to get the concentration.

\section{Acute toxicity}

The acute toxicity and lethality $\left(\mathrm{LD}_{50}\right)$ of the extracts was determined in mice using the method described by Lorke (16). Forty (40) adult male albino rats were used. Animals were bought from the animal house of the department of Pharmacology and Toxicology, University of Nigeria, Nsukka with no prior drug treatment. The rats were randomly allotted to eight (8) groups of five rats each on the basis of body weight (17). These rats were distributed in metabolism cages in the Department of Home Science, Nutrition and Dietetics, University of Nigeria Nsukka and maintained under standard environmental conditions (temperature and humidity).

\section{$>$ Experimental design}

The study was conducted for 29 days, which consists of 5days acclimatization, 1 day for inducement of anaemia, 2 days for establishment of anaemia and 21 days for experimental diets. There were six (6) test groups and two control groups as shown in table 1 below. The individual weights of the rats were taken at the beginning of the experiment and at the end of the experiment to determine the weight gain.

\section{Inducement of anaemia}

Anaemia was induced in rats in groups $A-G$ by single intra-peritoneal injection of $30 \mathrm{mg}$ Cyclophosphamide (Baxter Hithcare, India) $/ \mathrm{kg}$ body weight of rat on the $6^{\text {th }}$ day. After 48 hours ( $8^{\text {th }}$ day), the blood of the animals was drawn for hematological analysis, Animals that have hemoglobin value less than $11 \mathrm{mg} / \mathrm{dl}$ was considered anaemic and included in the study (18).

\section{$>$ Treatment trial}

All the rats were administered with normal poultry pellet and water throughout the period of the experiment. The aqueous leaf extracts were given orally early in the morning to the test groups in graded doses $(400 \mathrm{mg} / \mathrm{kg}$ and $800 \mathrm{mg} / \mathrm{kg}$ body weight) with the aid of an oral intubation tube for the twenty-one (21-day) treatment trials. The rats 
in group - $\mathrm{G}$ negative control (rats induced but not treated) and $\mathrm{H}$ - Positive control (normal rats, not induced and not treated) were the two control groups.

\section{Collection of blood samples}

Blood sample was collected from the retro-bulba plexus of the median canthus of the eye of the rat for biochemical analysis. Exactly $2 \mathrm{ml}$ of the blood sample was collected via a micro capillary tube into centrifuge tubes and allowed to clot for about 45 minutes at room temperature, after which they were centrifuged at 3000rpm for 5 minutes. The serum collected was transferred into Bijou bottles using pasteurized pipette and kept for biochemical indices determination.

\section{Hematological determination}

Biochemical indices determination was done at day $8^{\text {th }}, 15^{\text {th }}, 22^{\text {nd }}$ and $29^{\text {th }}$. The blood constituent's such as,
Neutrophils count and lymphocyte count according to Aka et al. (19).

\section{Determination of mineral Content of the leaves}

Mineral constituents of the leaves was determined by (Mn, Fe, Zn, P, and $\mathrm{Mg}$ ) metals using Atomic Absorption Spectrometer (AAS) according AOAC (20). Official methods of Analysis of the Association of Official Analytical Chemists, Washington D.C. $17^{\text {th }}$ Edn

\section{Statistical analysis}

The chemical composition and biochemical data collected were analyzed by using Statistical Product and Service Solution (SPSS) version 21.0. Means and Standard deviations of the data were obtained. One-way analysis of variance (ANOVA) and Duncan Studentised New Multiple Range Test were used to separate and compare means (20). The differences in means were considered significant at $5 \%$ probability

Flow chart for the processing of the three leaves.

\section{Fresh Sorghum \\ Bicolor leaves}

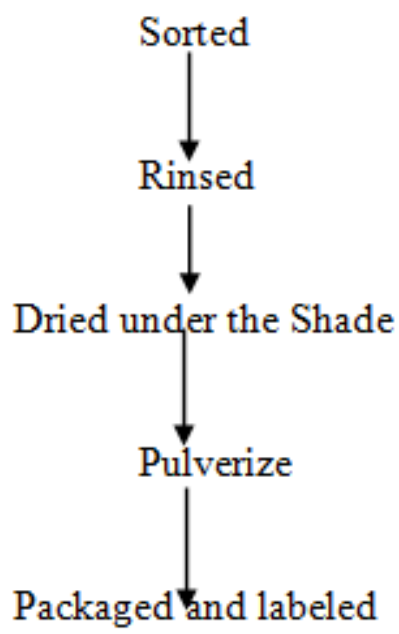

Fresh Carica papaya leaves

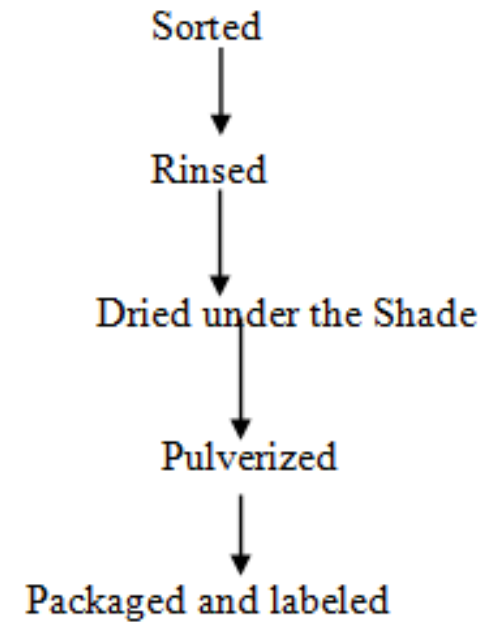

Fresh Hibiscus sabdariffa leaves

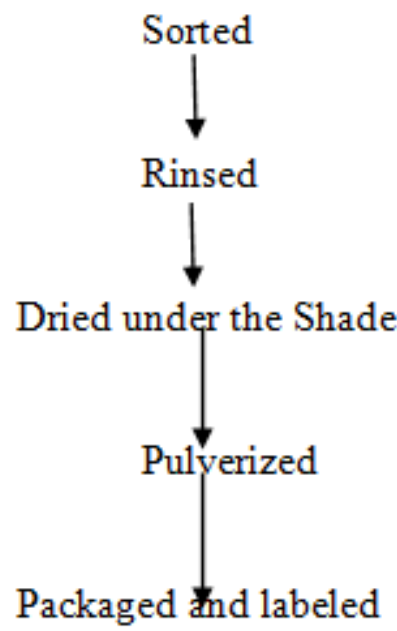

Flow chart showing the Preparation of the aqueous extract

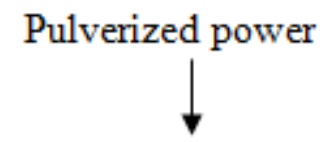

Addition of water<smiles>C1CC1</smiles>

Squeezing out the extract with water

Sieving using muslin cloth

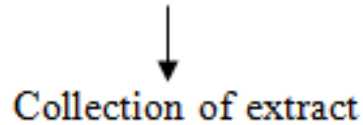


Mode offeeding

\begin{tabular}{|c|c|c|c|}
\hline Group & Doses of leaf extract & No of Rats & $\begin{array}{c}\text { Period of } \\
\text { administration } \\
\text { (days) }\end{array}$ \\
\hline SE400 & Anaemic rats treated with $400 \mathrm{mg} / \mathrm{kg}$ bw of Sorghum $b$. leaf extract & 5 & 21 \\
\hline SE800 & Anaemic rats treated with $800 \mathrm{mg} / \mathrm{kg}$ bw of Sorghum $\mathrm{b}$. leaf extract & 5 & 21 \\
\hline CP400 & Anaemic rats treated with $400 \mathrm{mg} / \mathrm{kg}$ bw of Carica $p$. leaf extract & 5 & 21 \\
\hline CP800 & Anaemic rats treated with $800 \mathrm{mg} / \mathrm{kg}$ bw of Carica p.leaf extract & 5 & 21 \\
\hline HB400 & Anaemic rats treated with $400 \mathrm{mg} / \mathrm{kg}$ bw of Hibiscus s.leaf extract & 5 & 21 \\
\hline HB800 & Anaemic rats treated with $800 \mathrm{mg} / \mathrm{kg}$ bw of Hibiscus $s$ leaf extract & 5 & 21 \\
\hline$-\mathrm{VECON}$ & Negative control (anaemic rats, not treated) & 5 & 21 \\
\hline$+\mathrm{VECON}$ & Positive control (normal rats) not- induced and not -treated & 5 & 21 \\
\hline
\end{tabular}

$\mathrm{Bw}=$ body weight

Table 1:- Dosage of extracts fed the groups of rats

\section{RESULTS}

\section{Mean body weight of rats administered the leaf extracts}

The group administered with $800 \mathrm{mg} / \mathrm{kgbw}$ Carica papaya leaf extract had the highest percentage increase in body weight $(41.61 \%)$ followed by group fed with $400 \mathrm{mg} / \mathrm{kg}$ bw of Hibiscus sabdariffa leaf extract (41.02), then group fed with $800 \mathrm{mg} / \mathrm{kg}$ bw Hibiscus sabdariffa $(40.48 \%)$, then the group fed $400 \mathrm{mg} / \mathrm{kg}$ bw of Carica papaya $(39.38 \%)$, the group fed with $400 \mathrm{mg} / \mathrm{kg}$ bw Sorghum bicolor leaf extract (34.01\%), and the group fed $800 \mathrm{mg} / \mathrm{kg}$ bw of Sorghum bicolor leaf extract had (30.95\%). The negative control (rats induced, not treated), had (15.73\%), then the positive control (normal rats, not induced, not treated) had $(19.47 \%)$. There was no significant $(\mathrm{P}<0.05)$ difference in the body weight before Induction among the different groups of rats. But the weight after induction, $1^{\text {st }}$ week after induction, $2^{\text {nd }}$ week and the $3^{\text {rd }}$ week after induction showed significant $(\mathrm{P}<0.05)$ difference in body weight among the groups.

\begin{tabular}{|c|c|c|c|c|c|c|}
\hline Group & Day 0 & Day 3 & Day 7 & Day 14 & Day 21 & \% Increase \\
\hline HB 400 & $144.54 \pm 2.94^{\mathrm{a}}$ & $141.19 \pm 3.47^{\mathrm{a}}$ & $154.89 \pm 5.11^{\mathrm{bc}}$ & $176.84 \pm 5.92^{\mathrm{b}}$ & $199.12 \pm 7.94^{\mathrm{b}}$ & $41.02 \uparrow$ \\
\hline HB 800 & $147.77 \pm 3.44^{\mathrm{a}}$ & $144.45 \pm 3.63^{\mathrm{a}}$ & $162.55 \pm 4.70^{\mathrm{bc}}$ & $183.81 \pm 6.08^{\mathrm{ab}}$ & $202.93 \pm 5.16^{\mathrm{ab}}$ & $40.48 \uparrow$ \\
\hline CP 400 & $147.26 \pm 2.92^{\mathrm{a}}$ & $143.02 \pm 2.25^{\mathrm{a}}$ & $160.71 \pm 1.49^{\mathrm{bc}}$ & $181.09 \pm 2.58^{\mathrm{ab}}$ & $199.34 \pm 6.79^{\mathrm{ab}}$ & $39.38 \uparrow$ \\
\hline CP 800 & $145.67 \pm 3.82^{\mathrm{a}}$ & $141.13 \pm 4.60^{\mathrm{a}}$ & $161.05 \pm 4.95^{\mathrm{bc}}$ & $176.94 \pm 6.36^{\mathrm{ab}}$ & $199.85 \pm 6.76^{\mathrm{ab}}$ & $41.61 \uparrow$ \\
\hline SE 400 & $146.85 \pm 3.53^{\mathrm{a}}$ & $143.78 \pm 3.58^{\mathrm{a}}$ & $159.58 \pm 5.66^{\mathrm{c}}$ & $175.36 \pm 5.19^{\mathrm{ab}}$ & $192.68 \pm 5.57^{\mathrm{ab}}$ & $34.01 \uparrow$ \\
\hline SE 800 & $147.90 \pm 3.18^{\mathrm{a}}$ & $146.54 \pm 3.51^{\mathrm{a}}$ & $160.13 \pm 1.15^{\mathrm{ab}}$ & $179.38 \pm 4.77^{\mathrm{a}}$ & $191.89 \pm 3.37^{\mathrm{a}}$ & $30.95 \uparrow$ \\
\hline -VECON & $144.53 \pm 4.28^{\mathrm{a}}$ & $143.71 \pm 5.18^{\mathrm{a}}$ & $145.18 \pm 4.77^{\mathrm{bc}}$ & $164.44 \pm 3.81^{\mathrm{ab}}$ & $166.32 . \pm 5.65^{\mathrm{ab}}$ & $15.73 \uparrow$ \\
\hline+ VECON & $145.51 \pm 4.62^{\mathrm{a}}$ & $155.62 \pm 8.57^{\mathrm{a}}$ & $168.33 \pm 7.50^{\mathrm{a}}$ & $178.45 \pm 8.41^{\mathrm{ab}}$ & $185.92 \pm 8.41^{\mathrm{ab}}$ & $19.47 \uparrow$ \\
\hline
\end{tabular}

Table 2:- Mean body weight of rats administered the leaf extracts (Hibiscus sabdariffa, Carica papaya and Sorghum bicolor)

Values are Means \pm SD; Values on the same column with different superscript were significantly different (p < 0.05$)$; HB400 $=$ anaemic rats treated with $400 \mathrm{mg} / \mathrm{kgbw}$ of Hibiscus sabdariffa leaf extract; HB800 = anaemic rats treated with $800 \mathrm{mg} / \mathrm{kg}$ bw of Hibiscus sabdariffa leaf extract; CP400 = anaemic rats treated with $400 \mathrm{mg} / \mathrm{kg}$ bw of Carica papaya leaf extract; CP800 = anaemic rats treated with $800 \mathrm{mg} / \mathrm{kg}$ bw of Carica papaya leaf extract; SE400 = anaemic rats treated with $400 \mathrm{mg} / \mathrm{kgbw}$ of Sorghum bicolor leaf extract; SE800 = anaemic rats treated with $800 \mathrm{mg} / \mathrm{kg}$ bw of Sorghum bicolor leaf extract; -VECON = negative control (anaemic rats, not treated); +VECON = positive control (not induced, not treated)

Neutrophils count of rats administered the leaf extracts (Hibiscus sabdariffa, Carica papaya and Sorghum bicolor)

The group fed with $400 \mathrm{mg} / \mathrm{kg}$ bw Sorghum bicolor leaf extract had the highest percentage decrease in neutrophils count $(28.23 \%)$ followed by group fed with $800 \mathrm{mg} / \mathrm{kg}$ bw of Hibiscus sabdariffa $(28.14 \%)$, then the group fed with $400 \mathrm{mg} / \mathrm{kg}$ bw Hibiscus sabdariffa leaf extract had (27.59\%), then the group fed with 400mg/kgbw Carica papaya leaf extract had (27.15\%), then the group fed $800 \mathrm{mg} / \mathrm{kgbw}$ Carica papaya leaf extract had $(21.11 \%)$ and the group fed with $800 \mathrm{mg} / \mathrm{kgbw}$ Sorghum bicolor had $(16.95 \%)$. The negative control (induced and not treated rats) had the highest $(29.13 \%)$ increase in their neutrophils count, the positive control (not induced and not treated rats) had the lowest decrease $(16.32 \%)$. There was no significance $(\mathrm{P}<0.05)$ difference in the neutrophils count at $3^{\text {rd }}$ day after induction but there was significant difference in neutrophils count at $1^{\text {st }}$ week after induction, $2^{\text {nd }}$ week and $3^{\text {rd }}$ week after induction. 
ISSN No:-2456-2165

\begin{tabular}{|c|c|c|c|c|c|c|}
\hline Groups & Before induction & $\begin{array}{c}\text { 3 days } \\
\text { after induction }\end{array}$ & $\begin{array}{c}\mathbf{1}^{\text {st }} \text { week } \\
\text { after induction }\end{array}$ & $\begin{array}{c}\mathbf{2}^{\text {nd }} \text { week after } \\
\text { induction }\end{array}$ & $\begin{array}{c}\mathbf{3}^{\text {rd }} \text { week after } \\
\text { induction }\end{array}$ & \% difference \\
\hline HB400 & $67.40 \pm 3.13^{\mathrm{a}}$ & $75.40 \pm 4.45^{\mathrm{a}}$ & $63.80 \pm 2.86^{\mathrm{b}}$ & $54.20 \pm 3.11^{\mathrm{b}}$ & $54.60 \pm 2.70^{\mathrm{bc}}$ & $27.59 \downarrow$ \\
\hline HB 800 & $68.20 \pm 2.77^{\mathrm{a}}$ & $73.20 \pm 3.11^{\mathrm{a}}$ & $68.20 \pm 1.30^{\mathrm{b}}$ & $54.00 \pm 2.74^{\mathrm{b}}$ & $52.60 \pm 1.95^{\mathrm{bc}}$ & $28.14 \downarrow$ \\
\hline CP400 & $63.20 \pm 5.07^{\mathrm{ab}}$ & $76.60 \pm 4.04^{\mathrm{a}}$ & $69.20 \pm 3.27^{\mathrm{b}}$ & $53.80 \pm 2.59^{\mathrm{b}}$ & $55.80 \pm 4.87^{\mathrm{bc}}$ & $27.15 \downarrow$ \\
\hline CP800 & $63.40 \pm 3.51^{\mathrm{ab}}$ & $75.80 \pm 4.60^{\mathrm{a}}$ & $68.60 \pm 3.13^{\mathrm{b}}$ & $54.80 \pm 4.21^{\mathrm{b}}$ & $59.80 \pm 5.12^{\mathrm{b}}$ & $21.11 \downarrow$ \\
\hline SE400 & $64.40 \pm 4.51^{\mathrm{ab}}$ & $75.80 \pm 4.49^{\mathrm{a}}$ & $64.60 \pm 1.95^{\mathrm{b}}$ & $53.60 \pm 3.78^{\mathrm{b}}$ & $54.40 \pm 4.04^{\mathrm{ab}}$ & $28.23 \downarrow$ \\
\hline SE800 & $60.80 \pm 6.72^{\mathrm{b}}$ & $70.80 \pm 5.72^{\mathrm{a}}$ & $63.40 \pm 2.61^{\mathrm{b}}$ & $56.20 \pm 5.31^{\mathrm{b}}$ & $58.80 \pm 8.93^{\mathrm{b}}$ & $16.95 \downarrow$ \\
\hline -VECON & $64.20 \pm 5.23^{\mathrm{ab}}$ & $71.40 \pm 4.56^{\mathrm{a}}$ & $77.80 \pm 7.16^{\mathrm{a}}$ & $83.20 \pm 7.66^{\mathrm{a}}$ & $92.20 \pm 4.92^{\mathrm{a}}$ & $29.13 \uparrow$ \\
\hline +VECON $^{\text {V }}$ & $63.00 \pm 3.16^{\mathrm{ab}}$ & $57.60 \pm 5.59^{\mathrm{b}}$ & $53.60 \pm 8.41^{\mathrm{c}}$ & $54.40 \pm 5.59^{\mathrm{b}}$ & $48.20 \pm 7.66^{\mathrm{c}}$ & $16.32 \downarrow$ \\
\hline
\end{tabular}

Table 3:- Neutrophils count of rats administered the leaf extracts (Hibiscus sabdariffa, Carica papaya and Sorghum bicolor)

Values are Means \pm SD; Values on the same column with different superscript were significantly different $(\mathrm{p}<$ $0.05) ; \mathrm{HB} 400=$ anaemic rats treated with $400 \mathrm{mg} / \mathrm{kgbw}$ of Hibiscus sabdariffa leaf extract; HB800 = anaemic rats treated with $800 \mathrm{mg} / \mathrm{kg}$ bw of Hibiscus sabdariffa leaf extract; $\mathrm{CP} 400=$ anaemic rats treated with $400 \mathrm{mg} / \mathrm{kg}$ bw of Carica papaya leaf extract; $\mathrm{CP} 800=$ anaemic rats treated with $800 \mathrm{mg} / \mathrm{kg}$ bw of Carica papaya leaf extract; SE400 = anaemic rats treated with $400 \mathrm{mg} / \mathrm{kgbw}$ of Sorghum bicolor leaf extract; SE800 = anaemic rats treated with $800 \mathrm{mg} / \mathrm{kg}$ bw of Sorghum bicolor leaf extract; VECON = negative control (anaemic rats, not treated); $+\mathrm{VECON}=$ positive control (not induced, not treated)

> Lymphocytes count of rats administered the leaf extracts (Hibiscus sabdariffa, Carica papaya and Sorghum bicolor)

The group fed with $400 \mathrm{mg} / \mathrm{kgbw}$ of Sorghum bicolor leaf extract had the highest percentage increase in lymphocyte count (105.41\%) followed by group administered with $800 \mathrm{mg} / \mathrm{kgbw}$ of Hibiscus sabdariffa (94.26\%), then the group fed with $400 \mathrm{mg} / \mathrm{kg}$ bw of Carica papaya leaf extract had (88.89\%), then the group fed with $400 \mathrm{mg} / \mathrm{kg}$ bw of Hibiscus sabdariffa leaf extract had (84.55\%), then the group fed with $800 \mathrm{mg} / \mathrm{kg}$ bw Carica papaya leaf extract had $(66.12 \%)$ and the group fed with $800 \mathrm{mg} / \mathrm{kg}$ bw of Sorghum bicolor leaf extract had $(43.84 \%)$. The negative control (induced and not treated rats) had $(18.92 \%)$ decrease in their lymphocyte count. Positive control (not induced and not treated rats) had the lowest (19.89\%) increase in their lymphocyte count. There was no significant $(\mathrm{P}<0.05)$ difference in the $3^{\text {rd }}$ day after induction among the different groups of rats. But the lymphocyte counts $1^{\text {st }}$ week after induction and $2^{\text {nd }}$ week and the $3^{\text {rd }}$ week after induction lymphocytes counts showed significant $(\mathrm{P}<0.05)$ difference among the groups. There was significant $(\mathrm{P}<0.05)$ decrease in the lymphocytes counts $(16.60 \%)$ of rats induced and not treated by the $1^{\text {st }}$ week after induction, $2^{\text {nd }}$ week and the $3^{\text {rd }}$ week after induction.

\begin{tabular}{|c|c|c|c|c|c|c|}
\hline Groups & $\begin{array}{c}\text { Before } \\
\text { induction }\end{array}$ & $\begin{array}{l}3 \text { days after } \\
\text { induction }\end{array}$ & $\begin{array}{l}1^{\text {st }} \text { week after } \\
\text { induction }\end{array}$ & $\begin{array}{c}2^{\text {nd }} \text { week } \\
\text { after induction }\end{array}$ & $\begin{array}{c}3^{\text {rd }} \text { week } \\
\text { after induction }\end{array}$ & $\%$ difference \\
\hline HB400 & $32.60 \pm 3.13^{\mathrm{a}}$ & $24.60 \pm 4.45^{b}$ & $36.20 \pm 2.86^{\mathrm{ab}}$ & $45.80 \pm 3.11^{\mathrm{b}}$ & $45.40 \pm 2.70^{\mathrm{ab}}$ & $84.55 \uparrow$ \\
\hline HB 800 & $31.80 \pm 2.77^{\mathrm{a}}$ & $24.40 \pm 12.36^{b}$ & $31.80 \pm 1.30^{\mathrm{bc}}$ & $46.00 \pm 2.74^{b}$ & $47.40 \pm 1.95^{\mathrm{a}}$ & $94.26 \uparrow$ \\
\hline CP400 & $36.80 \pm 5.07^{\mathrm{a}}$ & $23.40 \pm 4.04^{\mathrm{b}}$ & $30.80 \pm 3.27^{\mathrm{cd}}$ & $46.20 \pm 2.59^{b}$ & $44.20 \pm 4.87^{\mathrm{ab}}$ & $88.89 \uparrow$ \\
\hline CP800 & $36.60 \pm 3.51^{\mathrm{a}}$ & $24.20 \pm 4.60^{\mathrm{b}}$ & $35.40 \pm 2.41^{\mathrm{ab}}$ & $45.20 \pm 4.21^{\mathrm{b}}$ & $40.20 \pm 5.12^{\mathrm{b}}$ & $66.12 \uparrow$ \\
\hline SE400 & $35.60 \pm 4.51^{\mathrm{a}}$ & $22.20 \pm 7.82^{b}$ & $35.40 \pm 1.95^{\mathrm{ab}}$ & $46.40 \pm 3.78^{b}$ & $45.60 \pm 4.04^{\mathrm{ab}}$ & $105.41 \uparrow$ \\
\hline SE800 & $37.60 \pm 3.85^{\mathrm{a}}$ & $29.20 \pm 5.72^{\mathrm{ab}}$ & $36.60 \pm 2.61^{\mathrm{a}}$ & $43.80 \pm 5.31^{\mathrm{b}}$ & $42.00 \pm 7.52^{\mathrm{ab}}$ & $43.84 \uparrow$ \\
\hline -VECON & $36.20 \pm 5.31^{\mathrm{a}}$ & $29.60 \pm 3.97^{\mathrm{ab}}$ & $27.40 \pm 4.82^{\mathrm{d}}$ & $24.80 \pm 5.59^{\mathrm{a}}$ & $24.00 \pm 6.40^{c}$ & $18.92 \downarrow$ \\
\hline +VECON & $37.00 \pm 3.16^{\mathrm{a}}$ & $35.20 \pm 5.40^{\mathrm{a}}$ & $38.00 \pm 4.47^{\mathrm{a}}$ & $40.60 \pm 2.61^{b}$ & $42.20 \pm 3.11^{\mathrm{ab}}$ & $19.89 \uparrow$ \\
\hline
\end{tabular}

Table 4:- Lymphocytes count of rats $(10 * 3 / \mu 1)$ administered with leaves extract (Hibiscus sabdariffa, Carica papaya and Sorghum bicolor)

Values are Means \pm SD; Values on the same column with different superscript were significantly different ( $<<0.05)$; HB400 $=$ anaemic rats treated with $400 \mathrm{mg} / \mathrm{kgbw}$ of Hibiscus sabdariffa leaf extract; HB800 = anaemic rats treated with $800 \mathrm{mg} / \mathrm{kg}$ bw of Hibiscus sabdariffa leaf extract; CP400 = anaemic rats treated with $400 \mathrm{mg} / \mathrm{kg}$ bw of Carica papaya leaf extract; CP800 = anaemic rats treated with $800 \mathrm{mg} / \mathrm{kg}$ bw of Carica papaya leaf extract; SE400 = anaemic rats treated with $400 \mathrm{mg} / \mathrm{kgbw}$ of Sorghum bicolor leaf extract; SE800 = anaemic rats treated with $800 \mathrm{mg} / \mathrm{kg}$ bw of Sorghum bicolor leaf extract; $-\mathrm{VECON}=$ negative control (anaemic rats, not treated); +VECON = positive control (not induced, not treated) 
> Mineral composition of Hibiscus sabdariffa, Carica papaya and Sorghum bicolor leaves

The mineral compositions of the samples were presented in Table 4.2. Hibiscus s. leaves had zinc of $(6.36 \mathrm{mg} / 100 \mathrm{~g})$, Iron of (13.36mg/100g), Manganese of (25.56mg/100g), Phosphorus of (125.58mg/100g) and Magnesium of (12.28mg/100g). Carica p. had Zinc of $(6.56 \mathrm{mg} / 100 \mathrm{~g})$, Iron of $(12.55 \mathrm{mg} / 100 \mathrm{~g})$, Manganese of $(28.45 \mathrm{mg} / 100 \mathrm{~g})$, Phosphorus of $(133.35 \mathrm{mg} / 100 \mathrm{~g})$ and Magnesium of (13.36mg/100g). Sorghum b. had Zinc of (7.47mg/100g), Iron of (11.25mg/100g), Manganese of (33.34mg/100g), Phosphorus of $(155.58 \mathrm{mg} / 100 \mathrm{~g})$ and Magnesium of $(23.23 \mathrm{mg} / 100 \mathrm{~g})$.Sorghum $b$. had the highest value in Zinc, Manganese, Phosphorus, Magnesium and least value in Iron. Hibiscus s. had the least value in Zinc, Manganese, Phosphorus Magnesium and highest value in Iron, meanwhile Carica papaya as second in all the tested minerals.

\begin{tabular}{|c|c|c|c|c|c|}
\hline Samples & $\begin{array}{c}\text { Zinc } \\
(\mathbf{m g} / \mathbf{1 0 0 g})\end{array}$ & $\begin{array}{c}\text { Iron } \\
(\mathbf{m g} / \mathbf{1 0 0 g})\end{array}$ & $\begin{array}{c}\text { Manganese } \\
(\mathbf{m g} / \mathbf{1 0 0 g})\end{array}$ & $\begin{array}{c}\text { Phosphorus } \\
(\mathbf{m g} / \mathbf{1 0 0 g})\end{array}$ & $\begin{array}{c}\text { Magnesium } \\
(\mathbf{m g} / \mathbf{1 0 0 g})\end{array}$ \\
\hline HB & $6.36+0.01^{\mathrm{b}}$ & $13.36+0.01^{\mathrm{c}}$ & $25.56+0.01^{\mathrm{c}}$ & $125.58 \pm 0.01^{\mathrm{c}}$ & $12.28+0.01^{\mathrm{c}}$ \\
\hline CP & $6.56 \pm 0.01^{\mathrm{b}}$ & $12.55 \pm 0.01^{\mathrm{b}}$ & $28.45 \pm 0.01^{\mathrm{b}}$ & $133.35 \pm 0.01^{\mathrm{b}}$ & $13.36 \pm 0.01^{\mathrm{b}}$ \\
\hline SE & $7.47 \pm 0.02^{\mathrm{a}}$ & $11.25+0.01^{\mathrm{a}}$ & $33.34 \pm 0.01^{\mathrm{a}}$ & $155.58 \pm 0.01^{\mathrm{a}}$ & $23.23 \pm 0.01^{\mathrm{a}}$ \\
\hline
\end{tabular}

Table 5:- Mineral composition of Hibiscus sabdariffa, Carica papaya and Sorghum bicolor leaves (mg/100g)

Means \pm Standard deviation of triplicate determination Key: HB: Hibiscus sabdariffa, CP: Carica papaya, SE: Sorghum bicolor

Means values of different superscripts in the same column were differed significantly at $\mathrm{P}<0.05$

\section{DISCUSSION}

Mean body weight gain of the groups of rats fed Hibiscus sabdariffa, Carica papaya and Soghurm bicolor leaf extract showed moderate weight gain but was significantly $(\mathrm{P}<0.05)$ different. Rats administered with $800 \mathrm{mg} / \mathrm{kgbw}$ Soghurm bicolor leaf extract had the lowest percentage mean weight gain $(30.95 \%)$. This can be due to the higher content of reported crude fibre of Sorghum bicolour leaf. Dietary fibre intake provides many health benefits. A generous intake of dietary fiber reduces the risk for developing the following disease, stroke, hypertension, diabetes, obesity and certain gastrointestinal disorders (22, $23,24)$. There was a slight decrease in the neutrophils of the various leaf extracts treatment groups with the group fed $400 \mathrm{mg} / \mathrm{kgbw}$ Sorghum bicolor having the highest $(28.23 \%)$ decrease in their neutrophils. There was no significant $(\mathrm{P}<0.05)$ difference among the various treatment groups but was significantly $(\mathrm{P}<0.05)$ different when compared with the control groups. Neutrophils are a type of white blood cells. Neutrophils are a type of white blood cells that protect the body from infectious and heal damaged tissues $(24,25)$. They make up about 60 per cent of the white blood cell, Although the group administered with $400 \mathrm{mg} / \mathrm{kgbw}$ Sorghum bicolor had the highest $(51.92 \%)$ increase in their lymphocytes count but there was no significant $(\mathrm{P}<0.05)$ different among the various treatment groups but was significantly $(\mathrm{P}<0.05)$ different when compared with the control groups. Lymphocyte is the active white blood cell that is of fundamental importance in the immune system mechanism, there are function in building the body immune system is unequal $(26,27)$. This and couple with the high mineral content of the leaves such zinc, iron and magnesium could have the reason while the extract is used in the treatment of anaemia $(28,29)$

\section{CONCLUSION}

The effect administration of Sorghum bicolor, Carica papaya and Hibiscus sabdariffa leaf extracts irrespective of the dosage had the potential to increase weight, neutrophil and lymphocyte constituents of white blood cells. The leaves extract were abundant in zinc, iron, magnesium and phosphorus. The leaf extracts administration could restored anaemic condition of the rats and thus lent credence to its use in folklore medicine in the management of anaemia. Further study should exploit clinical trials on the leaf extracts to ascertain their efficacy in the management and treatment of nutritional anaemia.

\section{Declaration of interest}

The authors report no conflicts of interest. The authors alone are responsible for the design, data collection, writing and funding of this research

\section{REFERENCES}

[1]. World Health Organization (2011). Vector control of malaria, Available from: www.who.int/malaria/vector_control/en.

[2]. World Health Organization (2004). Nutritional Anaemia: Report of a WHO Scientific Group. Geneva, Switzerland: World Health Organization.

[3]. Akashi K.,Traver D., Kondo, M (1999). Lymphoid development from haematopoietic stem cells. International Journal Haematology, 69: 217-222.

[4]. Adedapo, A.A., Mogbojuri, O. M andEmikpe, B, O (2009.) Safety evaluations of the aqueous extract of the leaves of Moringa oleifera in rats. Journal Medicinal Plants Research, 3: 586-591.

[5]. GBD (2013). Mortality and causes of death, collaborators global, regional, and national age-sex specific all-cause and cause-specific mortality for 240 causes of death, 1990-2013: a systematic analysis for the global burden of disease study 2013.Lancet, 385 (9963):117-71.

[6]. WHO (2008) worldwide prevalence of anaemia global database on Anaemia1993-2006WHO global database on anemia.Available online: http://www.phytonbiotech.com 
[7]. Brabin, B.J., Premji Z. Verhoeff F. (2001). An analysis of anaemia and child mortality. Journal of Nutrition, 132 (6) 36-45.

[8]. Adias, T.C., Ajugwo, A.O., Erhabor, T andNyenke, C.U (2013). Effect of pumpkin extract (Telfairiaoccidentalis) on routine haematological parameters in acetone-induced oxidative stress albino rats. America Journal Food Science Technology, 1: 67-69.

[9]. Janz, T. G., Johnson, R. L and Rubenstein, S. D (2013). Anemia in the emergency department: evaluation and treatment.Journal of Emergency Medicine Practice,15(11): 1-15.

[10]. Vos, T., Flaxman, A. D.,Naghavi, M., Lozano, R., Michaud, C.,Ezzati, M., Shibuya, K and Salomon, J. A (2012). Years lived with disability (YLDs) for 1160 sequelae of 289 diseases and injuries 1990-2010: A systematic analysis for the Global Burden of Disease Study 2010. Lancet,380 (9859): 2163-96

[11]. Looff, B., Castillo, M and Smith J.B (2008). Poorer developmental outcome at 10 years with $12 \mathrm{mg} / \mathrm{l}$ ironfortified formula in infancy. Journal of Pediatric Academic Societies, 126(2): 427-36

[12]. Carter, R.C., Jacobson, J.L., Burden, M.J., ArmonySivan, R., Dodge, N.C and Angelilli, M.L (2010). Iron deficiency anaemia and cognitive function in infancy. International Journal of Child Development, 126(2), 427-34.

[13]. Stoltzfus, M.B (2004). Iron deficiency anaemia, comparative quantification of health risks: global and regional burden of disease attributable to selected major risk factors: WHO

[14]. Chevellier, A (1996). Encyclopedias of Medical Plant, London. Dorling Kindersley Ltd.(online), htt://www.chclibrary.org/plant.html.

[15]. Pushpam, K (2004). Valuation of medicinal plants for Pharmaceutical uses. Journal of Current Sciences 86 (7) $10-11$.

[16]. Lorke, D(1983). A new approach to practical acute toxicity testing. Archives of Toxicology, (53) 275287.

[17]. Luka, C., Tijjani, D and Habibu, W (2013). Comparative studies of the aqueous extracts of Ocimumgratissimum, Aloe vera, Brassica oleracea and Ipomaea batatas on some Biochemical Parameters in Diabetic rats. IOSR Journal of Pharmacy and Biological Sciences, 6(3): 23-29.

[18]. Olaleye, M. T (2007). Cytotoxicity and antibacterial activity of methanolic extract of Hibiscus sabdariffa. Journal of Medicinal Plants Research, 1(1): 009-013.

[19]. Aka, P. A., Okoli, C.O and Ndu,O.O (2007). Experimental Methods in Physiology andPharmacology. Abic Books Enugu \& Lagos, NigeriaPp:38

[20]. AOAC (2000). Official methods of Analysis of the Association of Official Analytical Chemists, Washington D.C. $17^{\text {th }}$ Edn

[21]. Steel, R.G. D. \& Torrie, J. H. (1960) Principle and procedures of statistics Mc Graw - Hill Book Company, NewYork,Pp:481
[22]. James, R., Randall, G and Zoe'Diana, D (2005). Zinc and Skin Health: Overview of Physiology and Pharmacology. Dermatology Surgery, 31(7): 838-847.

[23]. McLean, E., Coqswell, M., Egli, I., Wojdyla, D and Benoist, B (2009). Worldwide prevalence of Anaemia, WHO vitamin and mineral nutrition information system, 1993-2005. Public Health Nutrition, 12(4):444-54.

[24]. Hall, A. G andTilby, M. J (1992). Mechanisms of action of, and modes of resistance to, alkylating agents used in the treatment of haematological malignancies. Blood Reviews, 6 (3): 163-73.

[25]. Ajugwo, A. O., Mounbegna, P. E., Kemajou, T. S and Ofokansi, V. C (2017). Effects of Moringa oleifera leaves extract on haematological parameters of phenylhydrazine anaemia induced Wistar rats. International Journal of Public Health Safe, 2(4): 139144.

[26]. Pagnoux, C (2016). Updates in ANCA-associated vasculitis. European Journal of Rheumatology, 3 (3): 122-133.

[27]. Oladiji A.T., Jacob T.O andYakubu, M.T (2007). Anti-anaemic potentials of aqueous extract of Sorghum bicolor (L.) moench stem bark in rats. Journal of Ethnopharmacology,111(3):651-6.

[28]. Ganong, W (2005). Review of Medical Physiology. (22nd edtn), Lange Medical Books McGraw-Hill, New York, USA

[29]. Adefemi, O. S., Asadu, S. S., Oyakilome, I. G., Ajibulu, K. E and Asaolu, M. E (2012). Proximate and mineral compositions of Nigeria leafy vegetables. Journal of Food Research, 1(3): 214-218. 